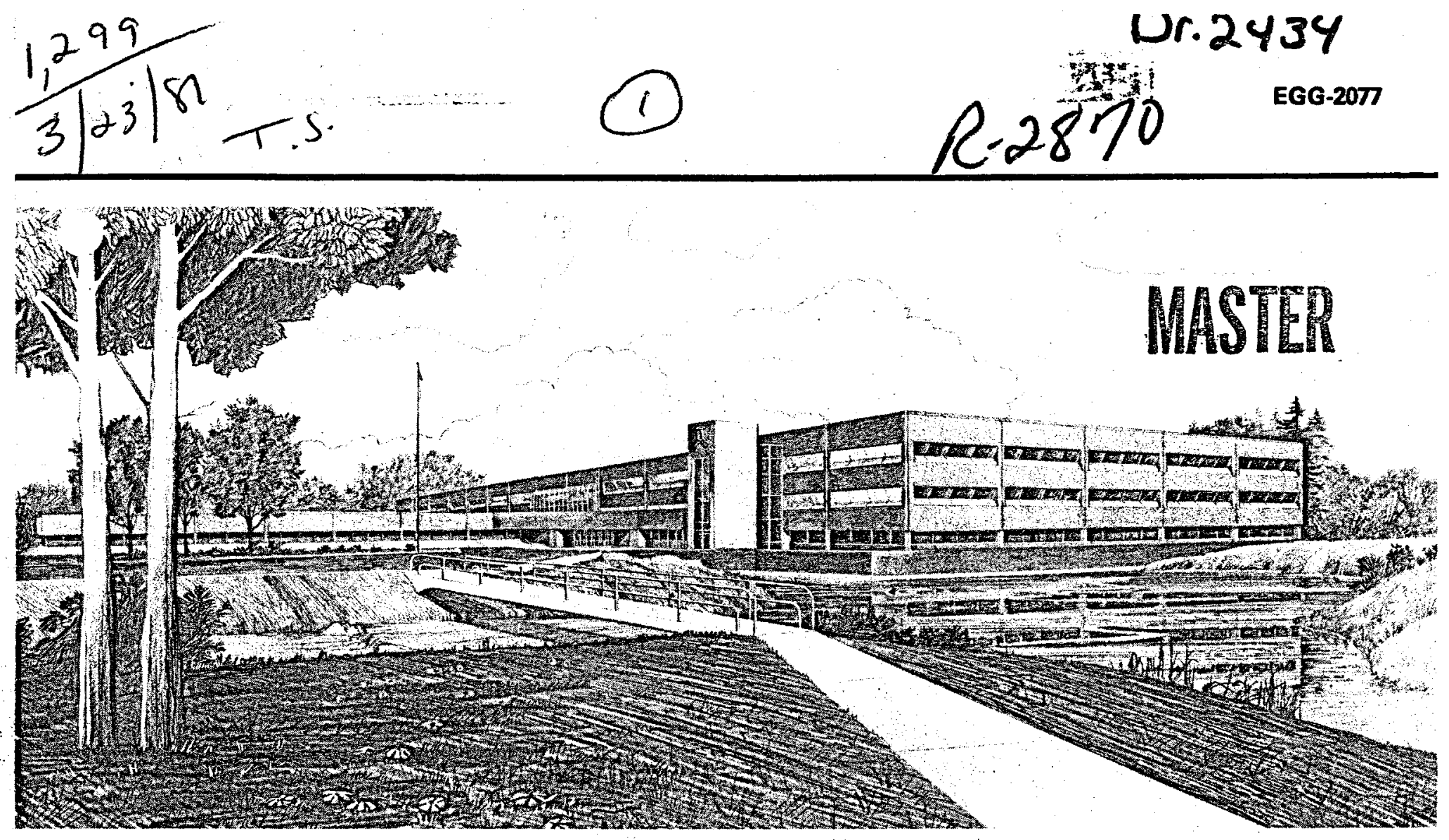

U.S. Department of Energy

Idaho Operations Office $\bullet$ Idaho National Engineering Laboratory

\title{
Semiannual Progress Report for the Idaho Geothermal Program April 1 to September 30, 1980
}

R. R. Ihrig, Ed.

March 1981 


\section{DISCLAIMER}

This report was prepared as an account of work sponsored by an agency of the United States Government. Neither the United States Government nor any agency Thereof, nor any of their employees, makes any warranty, express or implied, or assumes any legal liability or responsibility for the accuracy, completeness, or usefulness of any information, apparatus, product, or process disclosed, or represents that its use would not infringe privately owned rights. Reference herein to any specific commercial product, process, or service by trade name, trademark, manufacturer, or otherwise does not necessarily constitute or imply its endorsement, recommendation, or favoring by the United States Government or any agency thereof. The views and opinions of authors expressed herein do not necessarily state or reflect those of the United States Government or any agency thereof. 


\section{DISCLAIMER}

Portions of this document may be illegible in electronic image products. Images are produced from the best available original document. 


\author{
Printed in the United States of America \\ Available from \\ National Technical Information Service \\ U.S. Department of Commerce \\ 5285 Port Royal Road \\ Springfield, Virginia 22161 \\ NTIS Price Codes: Printed Copy $A 03$ \\ Microfiche $\mathbf{A} 01$
}

\title{
DISCLAIMER
}

This book was prepared as an account of work sponsored by an agency of the United States Government. Neither the United States Government nor any agency thereof, nor any of their employees, makes any warranty, express or implied, or assumes any legal liability or responsibility for the accuracy, completeness, or usefulness of any information, apparatus, product or process disclosed, or represents that its use would not infringe privately owned rights. References herein to any specific commercial product, process, or service by trade name, trademark, manufacturer, or otherwise, does not necessarily constitute or imply its endorsement, recommendation, or favoring by the United States Government or any agency thereof. The views and opinions of authors expressed herein do not necessarily state or reflect those of the United States Government or any agency thereof. 


\section{SEMIANNUAL PROGRESS REPORT FOR THE IDAHO GEOTHERMAL PROGRAM APRIL 1 TO SEPTEMBER 30, 1980}

R. R. Ihrig, Ed.

Published March 1981

EG\&G Idaho, Inc. Idaho Falls, Idaho 83415

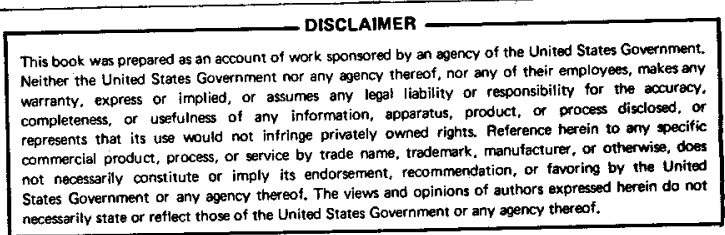

Prepared for the

U.S. Department of Energy

Idaho Operations Office

Under DOE Contract No. DE-AC07-76ID01570 


\begin{abstract}
This document summarizes progress of the Idaho Geothermal Program from April 1 to September 30, 1980. The report summarizes the completion of the 5-MW Pilot Power Plant at the Raft River Geothermal Test Site, modification of the similar, binary cycle Prototype Power Plant, and the water treatment program that studies environmentally safe ways to inhibit corrosion and scaling in geothermal power plants and investigates corrosion resistant materials. Studies of binary geothermal cycles using mixed hydrocarbon working fluids are described as part of the continuing search for ways to produce low-cost electricity from moderate-temperature geothermal fluids. Progress is reported on studies of direct contact heat exchanger concepts, heat rejection systems, and primary heat exchangers with augmentation. As part of the now-ended series of

an unsuccessful attempt to incubate common carp embryos in geothermal waters. The report mentions an experiment in revegetating disturbed land at Raft River and describes progress on DOE's new User Coupled Confirmation Drilling Program. An estimate is presented of the amount of hydrothermal energy that could be produced by the year 2000, with and without federal assistance, for electric generation and direct applications such as industrial process heat. Progress is reported on the Marketing Assistance Program, through which technical information and assistance is provided potential users and developers of geothermal resources. Also reported is progress in DOE's Program Opportunity Notice (PON) Program demonstration projects and Program Research and Development Announcement (PRDA) Program study projects.
\end{abstract} aquaculture experiments, a short report is given of 


\section{SUMMARY}

The Idaho Geothermal Program is sponsored by the Department of Energy. Its objectives are to develop, demonstrate, and encourage the use of hydrothermal energy. This document outlines progress made during the semiannual reporting period of April 1 to September 30, 1980.

At the Raft River Geothermal Test Site, construction of the 5-MW Pilot Power Plant is essentially complete. The thermal loop facility construction was completed during the reporting period, the turbine generator was aligned, the plant computer was installed, and software is being developed. The Safety Analysis Report was approved and released, and the plant operating report was issued. All preparations have been made for plant acceptance testing and operation. The three refurbished Centrilift pumps installed in the last reporting period failed again during testing. Three REDA geothermally hardened pumps are now either intalled or on order.

In the Water Treatment Program, tests continued in the search for ways to reduce silica and hardness of spent geothermal water to allow its use as cooling tower makeup. Bench-scale tests defined a treatment for the 5-MW plant's isobutane condenser. Chemical feed requirements for the plant's warm lime softener were also determined. Pilot cooling tower tests indicated a pretreatment method to eliminate pitting corrosion and that a dispersant prevents scale deposition. Bench-scale tests are being used to define a nonchromate corrosion treatment. Also, different materials are being evaluated for corrosion resistance in geothermal brines. In the experimental removal of silica with iron, calcium removal by ion exchange, and reduction of solids by reverse osmosis, iron was effective, but fouled the ion exchange resin and the reverse osmosis membrane. Removing iron from silica removal effluent will require a two-stage precipitation with a coagulant in the second stage.

The prototype power plant was modified to allow heat exchanger testing with either the shell and tube preheater/boiler or the new direct contact unit. The turbine and gearbox were returned to the manufacturer for repairs to the oil circulation system, and were reinstalled before plant modification was complete.
Studies continued on binary geothermal cycles using mixed hydrocarbons to find a working fluid that can produce low-cost electrical energy from moderate-temperature geothermal fluid. Preliminary estimates of heat exchanger size were made for several of the cycles studied. Detailed results of this study will be published, probably near the end of the next reporting period.

At the University of Utah, work continued on direct contact heat exchanger concepts and in some areas related to advanced concepts of other types. A project to compare the economics of six heat rejection systems concluded that three were competitive and that a final selection could only be made by studying detailed designs. A test unit, a liquid-liquid direct contact heat exchanger, was modified to allow visual and performance studies of several test parameter variables. Design curves were completed for filmwise condensing, and will be included in a summary report. Also, numerical studies are continuing on primary heat exchangers with augmentation to assess capital investment and performance tradeoffs between smooth and fin tube heat exchangers. This work should be completed during the next reporting period. In addition, experiments are being designed to compare a variety of heat transfer techniques for the heat rejection portion of the geothermal power cycle and a document is being written on direct contact geothermal power plants.

The two-year aquaculture experiment in the direct applications program was completed during the reporting period. During the experiment, common carp showed rapid, disease-free growth in geothermal water, far exceeding that of the control group in nongeothermal water. Embryos incubated in three geothermal water environments, however, did not survive for reasons not clear.

Reservoir engineering programs at Raft River began again in August, when funding became available. Data collection procedures were developed for pump testing and initial operation of the 5-MW power plant. Reservoir analysis for the Raft River Case Study was completed, and the draft report will probably be published early in FY 1981. 
Environmental monitoring continued at Raft River. The 1979 annual report on the geothermal environmental program was issued during the reporting period, and data collected on the ferruginous hawk in 1978 and 79 were published. Also published was the first in a series of reports on hydrologic and chemical monitoring of the shallow groundwater aquifers at Raft River. Another aspect of the environmental program is determining the best ways of revegetating disturbed land at Raft River. Researchers planted 10 species of grasses and shrubs, and found that nearly all are suitable for planned land restoration.

Raft River operations were upgraded with the addition of mobile firefighting capabilities. Also, eight employees were trained in firefighting techniques. The geothermal supply and disposal system was improved, and labor-saving changes were made in the location of stinger cable penetrations on four wells.

DOE initiated the User Coupled Confirmation Drilling Program during this reporting period to accelerate the commercialization of hydrothermal energy. This program, which shares the cost and risk of resource development, is managed by DOE-ID assisted, in part, by EG\&G Idaho, Inc. DOE issued a Solicitation for Cooperative Agreement Proposal in June and selected eight respondents for agreement negotiations, which will begin immediately.

EG\&G served as part of a task force charged with estimating the amount of energy that could be supplied by hydrothermal energy by the year 2000 with and without federal assistance. Results showed a $50 \%$ likelihood of as much as 12.8 gigawatts and a possibility that as much as $\mathbf{1 7 . 0}$ gigawatts could be on-line by the year 2000 with federal assistance. Without federal assistance, the corresponding numbers of gigawatts were 5.5 and 7.7, respectively. Preliminary analyses of direct applications showed a $50 \%$ probability that 0.5 quads would be on-line by the year 2000 with federal assistance and less than 0.2 quads without.

The Marketing Assistance Program, intended to promote the use of geothermal energy to replace fossil fuels, expanded its showing of exhibits and displays. A series of geothermal fact sheets was initiated, and state-specific slide/cassette shows, along with brochures and technical reports, were provided commercialization teams in ten western states. Requests for technical assistance and information continued to increase; 30 requests are being carried over into FY 1981 because of manpower limitations. During this reporting period, seven subcontracts were issued to engineering firms to help provide technical assistance. Four were completed, and one was ended by the requester's death. Subcontracting efforts will be increased to fulfill the program's responsibilities.

In this reporting period, EG\&G provided program management and technical support for 12 demonstration projects in the Program Opportunity Notice (PON) Program and 10 engineering and economic studies in the Program Research and Development Announcement (PRDA) Program. In the PRDA Program, four new technical and cost evaluations were completed, three studies were completed, and draft final reports for the other three projects are being reviewed. 


\section{CONTENTS}

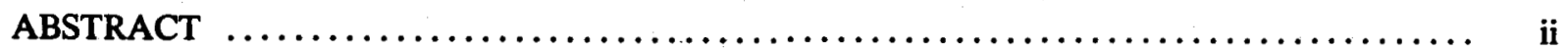

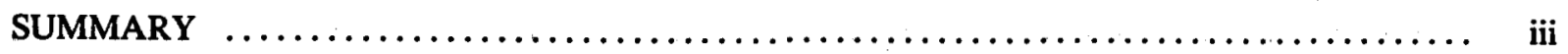

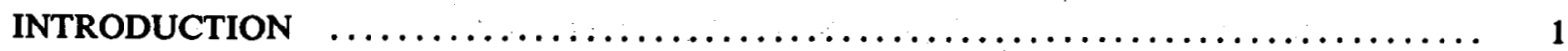

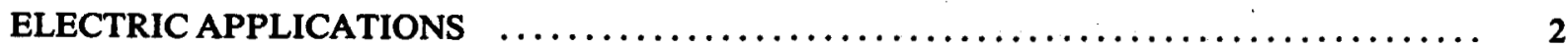

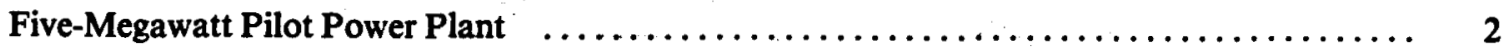

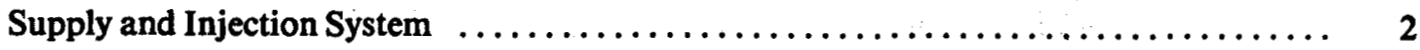

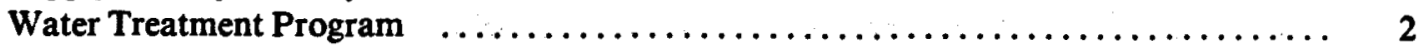

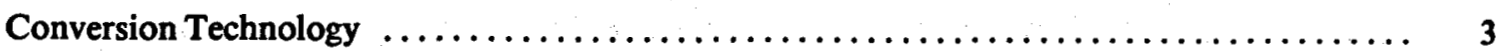

Prototype Power Plant $\ldots \ldots \ldots \ldots \ldots \ldots \ldots \ldots \ldots \ldots \ldots \ldots \ldots \ldots \ldots \ldots \ldots \ldots \ldots$

Direct Contact Heat Exchangers $\ldots \ldots \ldots \ldots \ldots \ldots \ldots \ldots \ldots \ldots \ldots \ldots, \quad 4$

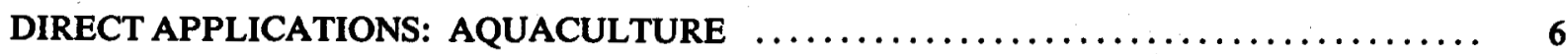

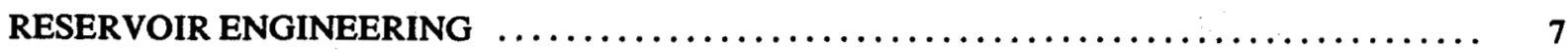

ENVIRONMENTAL CONSIDERATIONS $\ldots \ldots \ldots \ldots \ldots \ldots \ldots \ldots \ldots \ldots \ldots \ldots \ldots$

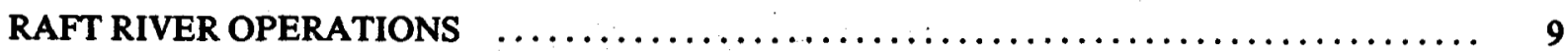

USER COUPLED CONFIRMATION DRILLING PROGRAM $\ldots \ldots \ldots \ldots \ldots \ldots \ldots \ldots \ldots, 10$

HYDROTHERMAL MARKET SHARE ESTIMATION $\ldots \ldots \ldots \ldots \ldots \ldots \ldots \ldots \ldots \ldots \ldots, 11$

Electric Generation $\quad \ldots \ldots \ldots \ldots \ldots \ldots \ldots \ldots \ldots \ldots \ldots \ldots \ldots \ldots \ldots \ldots \ldots \ldots \ldots \ldots, 11$

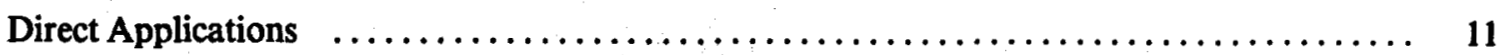

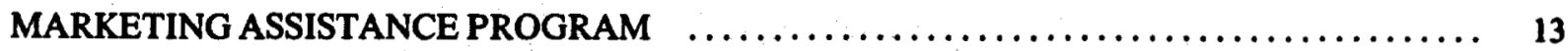

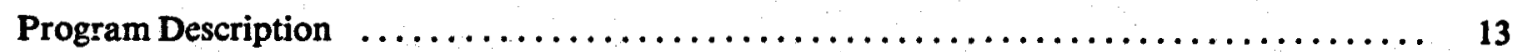

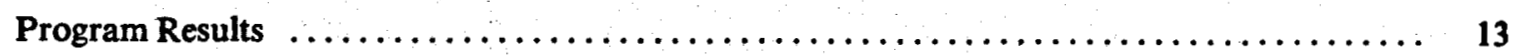

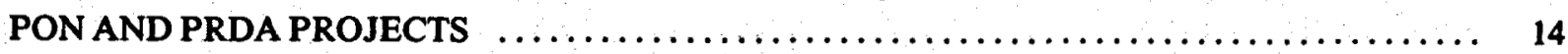

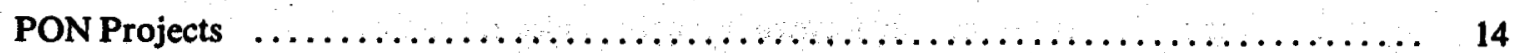

Ore-Ida Foods, Inc., Ontario, Oregon $\ldots \ldots \ldots \ldots \ldots \ldots \ldots \ldots \ldots \ldots \ldots \ldots \ldots$

Monroe City, Utah .......................................... 14

Haakon School District, Philip, South Dakota ........................ 14

St. Mary's Hospital, Pierre, South Dakota $\ldots \ldots \ldots \ldots \ldots \ldots \ldots \ldots \ldots \ldots \ldots \ldots \ldots \ldots$

Diamond Ring Ranch, Hakon, South Dakota $\ldots \ldots \ldots \ldots \ldots \ldots \ldots \ldots \ldots \ldots$

Elko, Nevada .......................................... 15

Warm Springs State Mental Hospital, Montana $\ldots \ldots \ldots \ldots \ldots \ldots \ldots \ldots \ldots \ldots .15$

Pagosa Springs, Colorado $\ldots . \ldots \ldots \ldots \ldots \ldots \ldots \ldots \ldots \ldots \ldots \ldots \ldots \ldots \ldots$ 


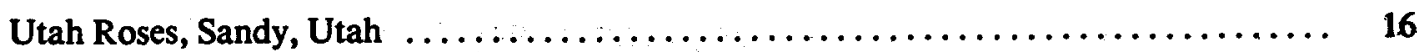

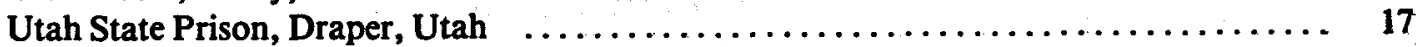

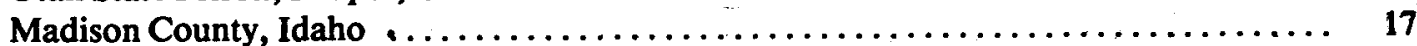

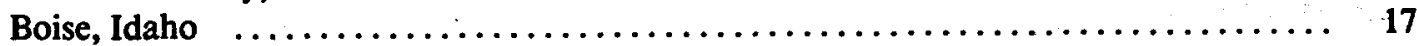

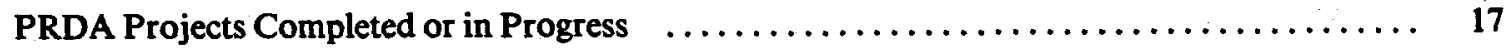

Residential and Commercial Space Heating and Cooling with

Possible Greenhouse Operation: Baca Grande Development,

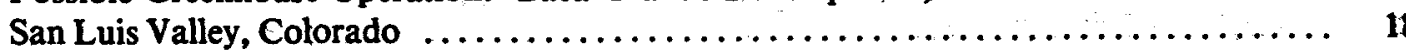

Direct Application of Geothermal Energy at the L'eggs Products Plant,

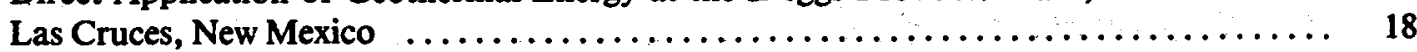

Direct Application of Geothermal Energy for Ethanol Production for

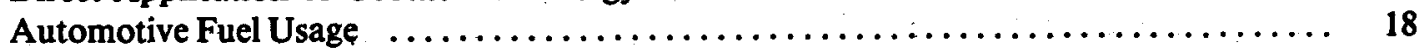

Evaluation of Direct Hot Water Geothermal Applications on the

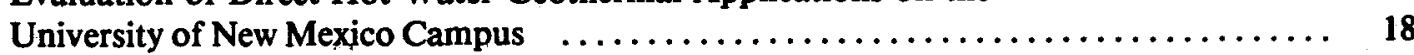

Municipal Geothermal Heat Utilization Plan for Glenwood Springs, Colorado ....... 18

Geothermal Space Heating in Poplar, Montana $\ldots \ldots \ldots \ldots \ldots \ldots \ldots \ldots \ldots \ldots . \quad 18$

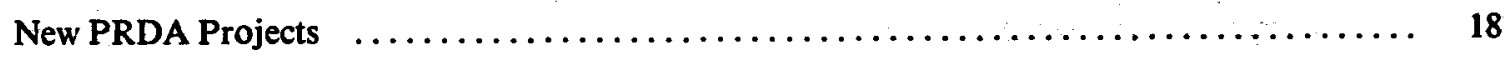

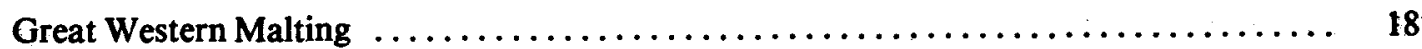

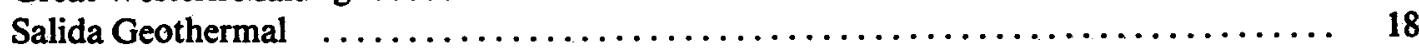

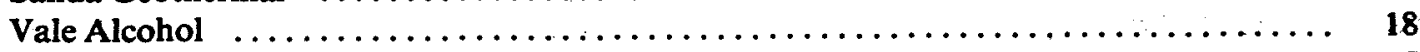

San Luis Valley Ethanol $\ldots \ldots \ldots \ldots \ldots \ldots \ldots \ldots \ldots \ldots \ldots \ldots \ldots \ldots \ldots \ldots \ldots \ldots \ldots \ldots, \quad 18$

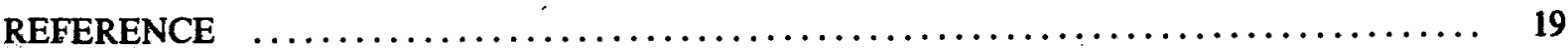

APPENDIX A-PUBLICATIONS OF THE IDAHO GEOTHERMAL PROGRAM $\ldots \ldots \ldots \ldots \quad 21$

FIGURE

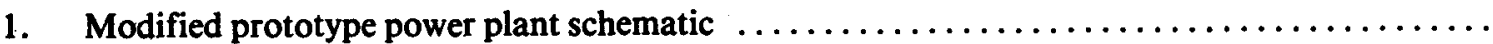

TABLES

1. Estimated gigawatts of national electric power with federal program $\ldots \ldots \ldots \ldots \ldots \ldots \ldots, 12$

2. Estimated gigawatts of national electric power without federal program $\ldots \ldots \ldots \ldots \ldots \ldots, 12$

3. Estimated quads per year of national hydrothermal nonelectric power

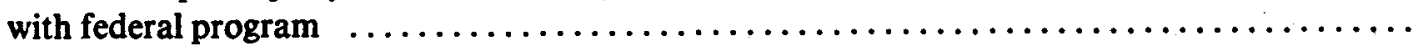

4. Estimated quads per year of national hydrothermal nonelectric power

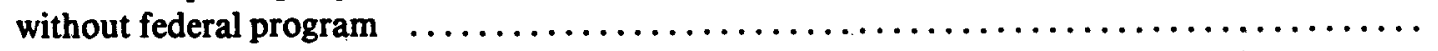

5. User assistance program activity summary_January 1977 through September $1980 \ldots \ldots \ldots 13$

A-1. EG\&G Idaho, Inc., formal reports of the Idaho Geothermal Program $\ldots \ldots \ldots \ldots \ldots \ldots \ldots$ 


\section{SEMIANNUAL PROGRESS REPORT FOR THE IDAHO GEOTHERMAL PROGRAM APRIL 1 TO SEPTEMBER 30, 1980}

\section{INTRODUCTION}

The Idaho Geothermal Program, sponsored by the Department of Energy (DOE), has conducted field experiments and demonstrations at the Raft River Geothermal Test Site since 1973. Located in south central Idaho, the geothermal area is the center of wide-ranging studies into various uses of the area's medium-temperature $\left(150^{\circ} \mathrm{C}\right)$ geothermal fluids. Applications include electric power generation, conversion technology (including research into direct contact heat exchangers), various kinds of direct applications, studies of water treatment methods, reservoir engineering, and environmental protection.
Personnel from DOE's Idaho National Engineering Laboratory (INEL) perform experiments and support functions at Raft River and, from DOE's facilities in Idaho Falls, assist DOE in conducting studies and in monitoring and administering various other programs. Among these programs are the commercialization of hydrothermal energy and providing technical assistance and information to potential developers of geothermal resources. Progress of these activities is summarized in this report. 


\section{ELECTRIC APPLICATIONS}

\section{Five-Megawatt Pilot Power Plant}

Except for minor items, construction is complete on the thermal loop facility. Construction and cold alignment of the turbine generator is complete, the plant computer was installed in the control room, and software is being developed.

The Safety Analysis Report was approved and released, and the "Operation of Raft River Pilot Plant" report was issued summarizing design limitations, operating set points, alarms, hazards, and precautions.

The environmental monitoring plan continues in effect as does air quality monitoring. The reservoir engineering and the State of Idaho requirements for FY-1980 have been satisfied.

Staffing for plant acceptance testing and operations is complete. Westec services finished subcontracted preparation of operational and maintenance procedures. Spare parts and operational materials were either received or are on order.

Supply and Injection System. The supply and injection (S\&I) system mechanical and wellhead instrumentation was completed during the reporting period. A high-pressure cutoff switch was installed in the 5-MW plant's boost pumps discharge to prevent inadvertent damage to the Transite pipe. A report was completed on the performance and operability of the supply and injection system.

The three refurbished Centrilift pumps installed in March failed during testing. They were removed and returned to Centrilift. At present, a REDA geothermally hardened pump is installed in RRGE-1, and two more REDA pumps are scheduled for delivery early in the next reporting period. A refurbished Peerless line shaft pump was installed in RRGP-3.

Water Treatment Program (D. Suciu). The purpose of the water treatment program is to define a total water treatment package for using spent geothermal fluid as cooling tower makeup. The program will define the chemical requirements for each water treatment component of the
5-MW pilot power plant. Each consists of silica and hardness reduction, prevention of scale deposition and corrosion, and treatment of blowdown to meet environmental standards.

Bench-scale tests were conducted during the reporting period to define a chemical cleaning and pretreating (prefilming) procedure for the carbon steel condenser tubes. This was a joint effort with Radian Corporation and Puckorius and Associates (consultants to EG\&G Idaho, Inc.). The treatment was defined and the isobutane condenser was cleaned and passivated in July and August and laid up in a wet condition. The condenser was later drained, dried, and laid up under a nitrogen blanket.

Chemical feed requirements for the 5-MW plant warm lime softener (silica and hardness reduction) were determined from data on the continuous flow precipitator-clarifier installed on the prototype power plant. Feed requirements are based on reducing the effluent water to 4 to $6 \mathrm{ppm}$ silica (as $\mathrm{SiO}_{2}$ ) and $20 \mathrm{ppm}$ hardness.

Results of pilot cooling tower tests indicate that with proper pretreatment, a chromate-phosphatezinc corrosion inhibitor program will eliminate the severe pitting corrosion. Tests also indicate that dispersant will effectively prevent scale deposition. The bench-scale cooling tower test units are being used to determine if a nonchromate corrosion treatment may be used in the 5-MW pilot power plant to eliminate the environmental, handling, and disposal problems associated with chromates.

The spinner test apparatus, which was used to screen various treatments before tests in the cooling tower test units, is being used to evaluate corrosion of alternative materials exposed to concentrated and aerated geothermal water.

Various water treatment equipment tests were conducted on the prototype power plant in conjuction with the Permutit Corporation. The tests evaluated calcium removal by ion exchange, silica precipitation with iron (supplied by dissolution of iron filings), and the use of reverse osmosis to reduce solids. Dissolved iron was effective in reducing silica to $20 \mathrm{ppm}$, but a considerable amount of iron was carried through the system, which fouled the ion exchange resin and the 
reverse osmosis membranes. The units were then operated independently rather than as an integrated system. These data show that ion exchange is a viable tool for calcium removal, eliminating the requirement for soda ash. The reverse osmosis unit was operated at $50 \%$ recovery and 96 to $98 \%$ salt rejection.

The unit was not operated long enough to determine operating costs or to project membrane lifetimes when used with geothermal brines. An extensive effort was made to remove the iron from silica removal effluent water to prevent resin fouling. Tests show that this will require two-stage precipitation and 1 to $2 \mathrm{ppm}$ of coagulate in the second stage. The system has been shut down and winterized.

\section{Conversion Technology}

\section{(J. Whitbeck)}

\section{Prototype Power Plant}

(O.J. Demuth and G. Mines)

Plant Modifications-During this reporting period, activities centered primarily around modification construction. The direct contact (sieve tray) heat exchanger and the ORNL fluted tube surface condenser were installed and the necessary modifications were made for testing these heat exchanger units. The new plant configuration (Figure 1) now has the flexibility to test with either the shell and tube preheater/boiler or the new direct contact unit.

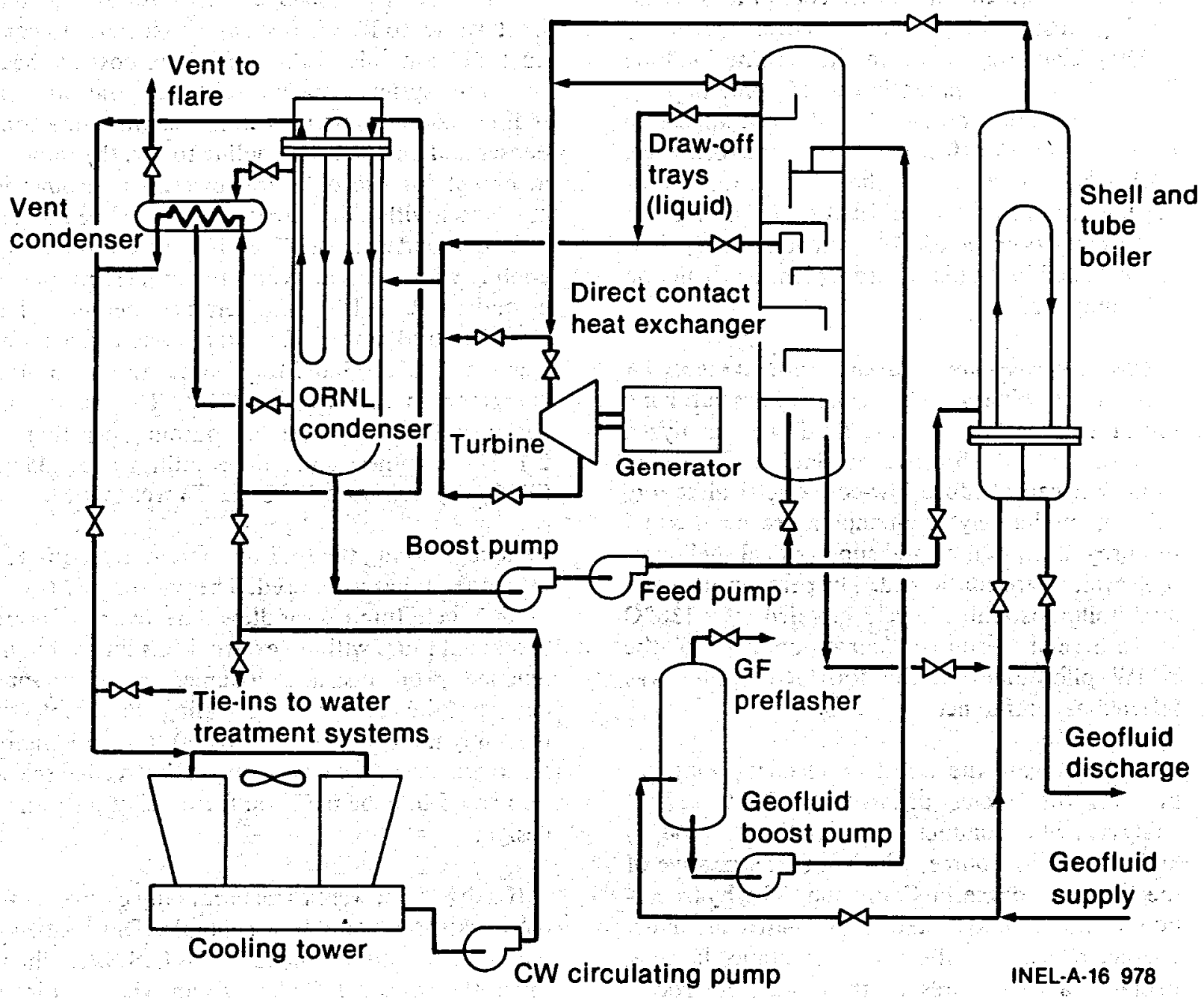

Figure 1. Modified prototype power plant schematic. 
Although the modification construction was started before this reporting period, most was done this past summer. The delay in receiving the ORNL condenser and other equipment prevented any construction activity for about two months. Modification construction was completed September 10. After a period of preparing the plant for operation and SO testing, the ORNL condenser tests were started on September 19 and continued through the end of the reporting period.

For the ORNL condenser tests, the shell and tube preheater/boiler was used to provide a data base with a "clean" system. When direct contact testing begins, condensables and water will be introduced into the working fluid system through the direct contact unit.

Turbine and Gearbox-The prototype turbine and gearbox were sent back to the manufacturer, the Barber Nichols Company, for inspection and repair to the oil circulation system in the gearbox. During disassembly, some debris (probably welding slag) was noted in the turbine blading. This debris had apparently caused some damage to the blades and nozzles, but did not appear to have adversely affected turbine performance. Barber Nichols' review of the test data taken during the auto-run tests indicated that the unit was performing as expected. The gearbox was repaired and installed in the plant before plant construction was completed.

Mixed Hydrocarbon Working Fluld Analysis-A number of binary geothermal cycles utilizing mixed hydrocarbon working fluids were analyzed with the overall objective of finding a working fluid that can produce low-cost electrical energy using a moderately low-temperature geothermal resource. Both boiling and supercritical shell-andtube cycles were considered. The performance of a dual-boiling isobutane cycle supplied by a $138^{\circ} \mathrm{C}$ hycirothermal resource (corresponding to the 5-MW pilot plant at the Raft River site) was selected as a reference.

To investigate the effect of resource temperature on the choice of working fluid, several analyses were conducted for a $182^{\circ} \mathrm{C}\left(360^{\circ} \mathrm{F}\right)$ hydrothermal resource, which is representative of the Heber resource in California. The hydrocarbon working fluids analyzed included methane, ethane, propane, isobutane, isopentane, hexane, heptane, and mixtures of those pure hydrocarbons. For comparison, two fluorocarbon refriger- ants were also analyzed. These fluorocarbons, R-115 and R-22, were suggested by Milora and Tester ${ }^{1}$ as resulting in high values of net plant geofluid effectiveness (Watt-hr/kg geofluid) at the two resource temperatures chosen for the study. Preliminary estimates of relative heat exchanger size (product of overall heat transfer coefficient times heater surface area, UA) were made for a number of the better performing cycles. Detailed study results are being prepared for publication.

Direct Contact Heat Exchangers (R. F. Boehm and H. R. Jacobs, University of Utah). During the reporting period, work continued in several, areas involving direct contact heat exchange concepts as well as some areas relating to advanced concepts of other types. These are summarized below. In addition, a major report surveying all of our direct contact work as well as some work done by others is in preparation.

Heat Rejection System Comparisons-A subcontract was let to R. W. Beck and Associates to conduct an economic evaluation of six possible heat rejection systems including (a) a conventional indirect cooling system with a shell and tube condenser and an open wet cooling tower, (b) same as a, except for use of a dry tower, (c) barometric condenser with a dry tower, (d) packed bed direct contact condenser with a dry tower, (e) direct cooling with a closed hybrid tower (performing as a condenser), and (f) barometric condenser with a closed hybrid tower. The study was carried out using a $182^{\circ} \mathrm{C}\left(360^{\circ} \mathrm{F}\right)$ resource and assuming isobutane as the working fluid. The plant was designed for $50-\mathrm{MW}(e)$ net output operating at $2-1 / 2 \%$ summer ambient conditions of $35^{\circ} \mathrm{C}$ $\left(95^{\circ} \mathrm{F}\right)$ dry bulb and $17^{\circ} \mathrm{C}\left(62^{\circ} \mathrm{F}\right)$ wet bulb.

In considering the indirect system, state-of-theart finned tubes were used. The packed bed tower used 2-inch Intalox saddles. The hybrid towers contained tubes with no external fins due to maintenance problems and assumed a continuous deluge of the tubes to avoid scaling. The results of the study indicate that systems (a), (e), and (f) are all competitive economically and that a final selection could only be made on the basis of a detailed design.

If a dry tower were to be used, only a direct contact condenser would be acceptable. This is consistent with the studies made in the U.S.S.R. which favor the so-called Heller system where a direct contact condenser is used with a closed tower. 
The U.S.S.R. uses the Heller system for conventional power plants since it does not require the presence of a clean cooling water source, water losses are negligible, maintenance costs are less, operating costs are less, and there are no problems with cooling water leaks into the system. Not all of these reasons for using a direct contact system are applicable to geothermal power plants; however, some are, and there may be others. The U.S.S.R. designs plants on the basis of a mean yearly temperature and not a temperature extremum, thus allowing for a power variation. In the present study, the maximum design temperature was exceeded only $2-1 / 2 \%$ of the time. To this extent, condensation and power output were affected. Costs also would be affected.

A detailed report is being prepared evaluating the study of the various heat rejection systems by University of Utah personnel. It will be completed shortly, together with recommendations for alternative systems that should be included in future studies.

Liquid-Liquid Direct Contact Heat Exchanger Modiffcation-A direct contact apparatus that has been used for a variety of tests, both at East Mesa as well as at the University, is currently undergoing modification. A visualization section is being designed for the top part of the spray column. The apparatus, which is slightly over $2 \mathrm{~m}$ long, will soon have its top half made of appropriate diameter concentric glass tubes. This modification, expected to be completed shortly, will allow visual and performance studies of such variables as droplet diameter, holdup, and injection distributions.

Filmwise Condensing-Analyses have been completed for condensation on a plane falling film and condensation on a film of coolant flowing over a sphere. The results of these efforts are being put in a form that can be used directly by a design engineer in the design of a packed bed condenser. Working curves have been developed for sizing direct contact packed bed condensers for both isobutane and pentane. These design curves will be included in the new summary report to be released later this year.

Studies of Primary Heat Exchangers with Augmentation-Numerical studies are continuing to assess capital investment and performance tradeoffs between smooth tube heat exchangers and fin tube heat exchangers for the geothermal power applications. In locations where the fluid is not prone to fouling, the film tube approach may have some merit. We found that for simple geometries, fin tube arrangements costing up to six times more per unit area than smooth tube arrangements may be cost effective. Both heat transfer and frictional pressure drop are being considered in a variable property heat exchanger calculation scheme. This work will be completed during the next semiannual period.

Multiple Purpose Meat Transfer ApparatusExperiments are being designed to compare a variety of heat transfer techniques for the heat rejection portion of the geothermal power cycle. Included will be options for conventional shell and tube configurations, fluidized bed arrangements, ammonia reboiling schemes, and direct contact designs. Near the end of the reporting period, fabrication began on a multiple purpose apparatus to accomplish these experiments.

Direct Contect Geothermal Power Plant Document-This document is currently in the writing stage; however, additional data are needed to complete the sections dealing with heat rejection, augmented heat exchange surfaces, and large-scale direct contactors. The data on large-scale direct contactors await information on the BarberNichols Engineering system currently installed at East Mesa. Data have been slow in coming due to turbine problems; however, preliminary results indicate that the equipment is behaving as designed by Professor Jacobs and as described in our contribution to the Geothermal Sourcebook. 


\section{DIRECT APPLICATIONS: AQUACULTURE}

\section{(R. P. Breckenridge)}

In July of 1980, EG\&G Idaho, in conjunction with the University of Idaho, completed a twoyear contract for the Raft River Aquaculture Research Project. The objectives of the 1980 research were to determine the effects of geothermal water on (a) gonadal development of common carp (Caprinus carpio) and (b) commón carp embryogenesis. This type of research would provide information for evaluating the effect of geothermal waters on the reproductive capacity of carp.

Two groups of carp were induced to spawn by natural means. The resultant eggs from both groups were tested in triplicate for rate of embryogenesis and percent survival in three water environments of different ionic content: undiluted geothermal water $(3500 \mu \mathrm{mhos} / \mathrm{cm})$, deionized intermediate test water $(2250 \mu \mathrm{mhos} / \mathrm{cm})$, and deionized control water $(1000 \mu \mathrm{mhos} / \mathrm{cm})$. All embryos experienced complete mortality between 80 and 125 hours post-fertilization in incubating waters with saturated oxygen levels and constant temperature, regardless of the ionic content. Embryo tissue analyses indicated that the concentrations of total dissolved solids (TDS) do not affect the reproduction capacity of the carp; however, the circular fiberglass tanks in which the fish were kept did not provide a suitable spawning environment. This fact was very evident when carp fingerlings appeared in discharge ponds downstream from the fish tanks.
The results of this study indicated that growth of the common carp was excellent in geothermal water, far exceeding that of the control in nongeothermal water. There were no clinical signs of any infectious or noninfectious diseases present during the year-long culture period. In the physiological tests performed, no measurable differences were noted between test fish in geothermal water and control fish. Bioaccumulation of some heavy metals (i.e., $\mathrm{Pb}, \mathrm{Hg}, \mathrm{Zn}$ ) in the edible portions of the fish flesh occurred during the cultural period, but did not reach levels of concern for human consumption.

Some of the questions generated during this study were:

1. What are the effects of diet on the production of viable gametes?

2. Did heavy metals bioaccumulate on the oocytes?

3. What are optimum spawning environments for geothermal aquacultural programs?

These questions should be the focus of future research projects concerned with using geothermal water to produce an economic aquaculture resource. 


\section{RESERVOIR ENGINEERING}

\section{(S. G. Spencer)}

The reservoir engineering programs at Raft River were reinitiated in August when funding became available. Activities at the end of the reporting period included the development of data collection procedures for pump testing and initial operation of the power plant. A long-term flow test was conducted at RRGE-1 and the results of the test are now being analyzed.
Reservoir analysis for the Raft River Case Study was completed and the draft case study report is nearly finished. Arrangements are currently being made to publish the case study in early FY-81. 


\title{
ENVIRONMENTAL CONSIDERATIONS
}

\author{
(S. G. Spencer)
}

Environmental monitoring at Raft River during the last six months included air quality, meteorology, water quality, hydrology, seismicity, and terrestrial and aquatic ecology. The 1979 Annual Report, "INEL Geothermal Environmental Programs," was issued during this period (refer to Appendix A for a complete listing).

Raptor data collected during 1978 and 1979 were issued in a report (listed in Appendix A) published in September. Research conducted from 1972 to 1977 on the nesting activity of the ferruginous hawk population combined with the 1978-1979 data gives a continuous nine-year breeding survey. Black-tailed jackrabbits (Lepus californicus) were found to be the major prey of the large raptor species. Peak population levels of 280 to 300 jackrabbits per $\mathrm{km}^{2}$ were recorded during 1978 and 1979. The high density was responsible in part for the abundant raptor population and the high fledging rates found during these two years. The numbers of active territories and young fledged per nest during the period of 1972 to 1980 suggest that the nesting success of the ferruginous hawk is closely tied to the black-tailed jackrabbit population, which cycles approximately once every 7 to 10 years.

The first in a series of reports on hydrologic and chemical monitoring of the shallow groundwater aquifers in Raft River was issued in September (refer to listing in Appendix A).

Monitoring of wells during two 21-day injection tests at the Raft River Geothermal Injection Well-6 (RRGI-6) indicates two types of response in the shallow aquifer system:

1. The water level in Monitor Well-4 (MW-4) increased an average of $0.4 \mathrm{~m} /$ week during injection, indicating direct fracture connection between the injection zone and the aquifer penetrated by MW-4.

2. Water levels in MW-5, MW-6, and MW-7 showed a "step function" decrease, which coincided with the period of the injection tests. Analyses indicate that this response may be caused by elastic deformation in the aquifer matrix.

As part of research to determine the best methods of revegetation to be used at Raft River, 7.7 hectares of disturbed ground were planted with 10 species of grasses and shrubs. Initial results from this effort indicate that nearly all the species are feasible for planned land restoration at the site. 


\section{RAFT RIVER OPERATIONS}

Firefighting equipment was installed on the pumper truck, providing the Raft River Geothermal Test Site with an adequate mobile fire protection unit. Eight employees were trained in firefighting by EG\&G's fire and safety personnel and by the Malta Fire Department.

The geothermal water supply manifold at RRGE-1 was completed. This gives great flexibility in the supply and disposal of the geothermal water. Improved stinger cable penetrations were designed and installed on Wells 1, 2, 3, and 5. By locating the stinger penetrations below the master valve, 8 to 12 hours are saved each time work is done on the well.

Piping was laid to supply geothermal water from the pond at RRGP-4 to the Kimberly Agriculture Experiment. This project is a DOE-ID administered contract with the University of Idaho Extension service. The pond at RRGE-1 was lined, which makes it possible to store warmup water from Well 3 until it can be reinjected. 


\title{
USER COUPLED CONFIRMATION DRILLING PROGRAM
}

\author{
(M. R. Dolenc and J. A. Strawn)
}

An industry survey conducted in the summer of 1979 disclosed that to accelerate commercialization of hydrothermal energy, one of the foremost requirements is to reduce the risk and costs of exploration. In response to this requirement, DOE initiated the User Coupled Confirmation Drilling Program.

This program will speed hydrothermal industrialization by absorbing some of the high risk and cost while developing an experienced industry in the private sector that will reduce future risk and that can carry on development without future federal aid. The program will share the cost of exploration, drilling, flow testing, reservoir engineering, and injection well drilling (if required). Cost-sharing or financing for - the utilization system to be installed once the reservoir is confirmed are not covered under this program. The federal percentage of cost-share will be determined by a negotiated formula based upon usability of the thermal fluids intersected by the drilling. For a completely successful project, the DOE costshare will be $20 \%$, whereas for a completely unsuccessful project, the DOE cost-share will be $90 \%$. The degree of success and the corresponding DOE cost-share are expected to range between these extremes for individual projects.

The program is being managed for DOE Headquarters by the Idaho Operations Office of DOE with assistance from the Earth Science Laboratory of the University of Utah Research Institute, EG\&G Idaho, Inc., and the Nevada Operations Office of DOE.

Earlier this year, a series of public information meetings was held in Washington, D.C., Denver, and Oakland to describe the program. Then on June 13, the first Solicitation for Cooperative Agreement Proposal (SCAP) was issued. Proposals came in from across the nation, and DOE selected eight firms with which to negotiate cooperative agreements for federal support. Two projects each are in Oregon and California, and one each is in Idaho, Nevada, Colorado, and New York.
Proposers selected, their projects, and total estimated project costs for resource confirmation are:

1. Magic Resource Investors of Sun Valley, Idaho; Magic Hot Springs Landing, Blaine County, Idaho; heat for an ethanol production plant; $\$ 1,209,328$.

2. Technology International, Inc.; Vale Hot Springs near Vale, Oregon; thermal energy for a fuel alcohol plant; $\$ 1,472,000$.

3. Hydrothermal Energy Corporation; Geothermal Hotel Project; Reno, Nevada; space heating, air conditioning, domestic hot water, and snow melting for the hotel; $\$ 1,904,710$.

4. City of Alamosa, Colorado; thermal energy to run a barley malting plant, and secondarily to provide space heating for Adams State College; $\$ 726,800$.

5. Taylor Instrument Company, Division of Sybron Corporation; Rochester, New York; space heating for the Sybron/Taylor Instrument complex; $\$ 555,125$.

6. Northwest Geothermal Corporation; Lakeview, Oregon; space- and waterheating within Lakeview, Oregon, central business district; $\$ 402,000$.

7. GeoProducts Corporation; Wendel, Lassen County, California; heat to dehydrate wood residues burned for electrical generation, and secondarily to preheat boiler feed water and combustion air; $\$ 1,493,584$.

8. Ms. Connie Wilson; Calistoga, California; energy for space heating, domestic hot water supply, and heating of pools and spas for the Wine Valley Inn; \$120,200.

Negotiations with the selected proposers will begin immediately and project status will be reported in the next semiannual report. 


\title{
HYDROTHERMAL MARKET SHARE ESTIMATION
}

\author{
(T. W. Lawford)
}

The goal of this project is to provide realistic estimates of the amount of energy that could be supplied by hydrothermal energy by the year 2000 for electric generation, space conditioning, and industrial process heat. A secondary goal is to evaluate the effectiveness of federal programs aimed at accelerating the use of hydrothermal energy.

The project was undertaken by a task force comprising EG\&G, Earth Science Laboratory of the University of Utah Research Institute (ESL), Engineering and Economics Research (EER), the New Mexico Energy Institute (NMEI), Technecon Analytic Research, and Western Energy Planners, Ltd. (WEPL).

The task force approached the project by first developing an analytical model that accurately represents the investment decision policy of the expected participants in hydrothermal energy production and use. The model was fed data representing projections of the future economic environment, cost parameters of hydrothermal energy utilization, and physical data on the hydrothermal resource base of the United States. EG\&G's major role was supplying the cost parameters and surveying industry to establish the investment decision policies of industries with a potential for using hydrothermal energy:

\section{Electric Generation}

EG\&G supplied basic cost data for electric generation for both hydrothermal plants and competing conventional sources. Power plant performance data were developed for dual flash steam and binary plants as a function of resource temperature and geothermal brine salinity. Capital costs of the power plants were developed as functions of the same parameters. Geothermal production and injection well costs were developed from public and proprietary data for various depths and rock hardness. Field system capital costs to supply the power plants were also evaluated, as were $O \& M$ costs for the plant and field system.

Results of the analyses were prepared in a form that estimated the number of gigawatts (1000 megawatts) that would be generated, in fiveyear increments, and the percentage of likelihood that these numbers would be achieved. One set of projections assumed federal programs; the other did not (Tables 1 and 2). Assuming the assistance of federal programs, Table 1 shows a $50 \%$ likelihood of as much as 12.8 gigawatts and a possibility of as much as $\mathbf{1 7 . 0}$ gigawatts on-line by the year 2000 .

\section{Direct Applications}

Industries with the potential to use hydrothermal energy for process heat were selected by means of a progressive screening process; 455 industries. with process heat. requirements greater than $10^{12} \mathrm{Btu} / \mathrm{yr}$ were initially identified. Of these, only 65 required process heat under $204^{\circ} \mathrm{C}\left(400^{\circ} \mathrm{F}\right)$. Further screening and combining resulted in the selection of 25 generic industrial groups covering 41 basic 4-digit Standard Industrial Classification (SIC) categories. An interview form was designed and 417 companies were contacted to establish their investment decision policies with regard to energy.

EG\&G also supplied capital cost data for the utilization of hydrothermal energy for several industries, which were generalized over all of the industries considered.

Preliminary results of the analyses for direct applications shows a $50 \%$ probability that 0.5 quads (one quad $=10^{15} \mathrm{Btu}$ ) would be online by the year 2000 with the full federal program. With no federal program, less than 0.2 quads would be on-line by that time with the same probability (Tables 3 and 4). 
Table 1. Estimated gigawatts of national electric power with federal program

\begin{tabular}{|c|c|c|c|c|c|c|}
\hline \multirow{2}{*}{$\begin{array}{c}\text { Likelihood } \\
(\%) \\
\end{array}$} & \multicolumn{6}{|c|}{ Year } \\
\hline & 1980 & $\underline{1985}$ & 1990 & 1995 & 2000 & 2005 \\
\hline$>0$ & 1.0 & 1.8 & 3.8 & 9.1 & 17.0 & 21.0 \\
\hline$>10$ & 1.0 & 1.8 & 3.8 & 8.9 & 16.8 & 20.4 \\
\hline$>50$ & 1.0 & 1.7 & 3.7 & 7.9 & 12.8 & 15.4 \\
\hline$>90$ & 1.0 & 1.7 & 3.6 & 7.1 & 10.8 & 12.1 \\
\hline
\end{tabular}

Table 2. Estimated gigawatts of national electric power without federal program

\begin{tabular}{ccccccc}
\hline & \multicolumn{7}{c}{ Year } \\
\cline { 2 - 6 } $\begin{array}{c}\text { Likelihood } \\
(\%)\end{array}$ & 1980 & 1985 & $\underline{1990}$ & $\underline{1995}$ & $\underline{2000}$ & $\underline{2005}$ \\
\cline { 2 - 7 }$>0$ & 1.0 & 1.7 & 2.7 & 4.7 & 7.7 & 9.4 \\
$>10$ & 1.0 & 1.7 & 2.6 & 4.3 & 7.2 & 8.2 \\
$>50$ & 1.0 & 1.7 & 2.6 & 3.8 & 5.5 & 6.0 \\
$>90$ & 1.0 & 1.5 & 2.4 & 3.2 & 4.2 & 4.6 \\
\hline
\end{tabular}

Table 3. Estimated quads per year of national hydrothermal nonelectric power with federal programa

\begin{tabular}{cccccc}
\hline & \multicolumn{5}{c}{ Year } \\
\cline { 2 - 5 } $\begin{array}{c}\text { Likelihood } \\
(\%)\end{array}$ & 1980 & $\underline{1985}$ & $\underline{1990}$ & $\frac{1995}{2000}$ \\
\cline { 3 - 6 }$>5$ & 0.016 & 0.184 & 0.424 & 0.602 & 0.744 \\
$>50$ & 0.012 & 0.125 & 0.304 & 0.433 & 0.531 \\
$>95$ & 0.010 & 0.080 & 0.207 & 0.296 & 0.358
\end{tabular}

a. Includes colocated district heat, colocated and relocated agricultural/industrial, enhanced oil recovery, and ethanol plants.

Table 4. Estimated quads per year of national hydrothermal nonelectric power without federal programa

\begin{tabular}{c}
$\begin{array}{c}\text { Likelihood } \\
(\%)\end{array}$ \\
\hline$>5$ \\
$>50$ \\
$>95$
\end{tabular}

\begin{tabular}{lllll}
\multicolumn{5}{c}{ Year } \\
\hline 1980 & 1985 & 1990 & 1995 & 2000 \\
0.016 & 0.067 & 0.140 & 0.203 & 0.286 \\
0.012 & 0.040 & 0.086 & 0.130 & 0.177 \\
0.010 & 0.023 & 0.051 & 0.077 & 0.101
\end{tabular}

a. Includes colocated district heat, colocated and relocated agricultural/industrial, and enhanced oil recovery. 


\section{MARKETING ASSISTANCE PROGRAM \\ (W. J. Toth, I. A. Engen, and F. L. Meltzer)}

\section{Program Description}

Under DOE direction, EG\&G Idaho provides technical information and assistance to anyone interested in the direct application of geothermal energy. Information is provided to the public, private, and technical sectors through exhibits, displays, and presentations at conferences and meetings and through the distribution of pamphlets, brochures, and fact sheets. Technical assistance is provided to requesters in the Rocky Mountain Basin and Range Region through in-house engineers or through subcontracts to architectural and engineering firms. Up to 100 man-hours of assistance are available on a first-come, staff-available basis. By assisting requesters with technical information and initial feasibility determinations, users are encouraged to explore the development of geothermal resources further and to continue their efforts to the eventual utilization of geothermal energy to replace fossil fuels.

\section{Program Results}

To date, information dessemination efforts have been extensive. Geothermal exhibits and displays were expanded and shown at 18 conferences and expositions in ten states and the District of Columbia. It is estimated that almost 400,000 participants were able to view these materials and to receive more information from EG\&G personnel. Supplies of the popular and useful "Rules of Thumb" brochure were exhausted and a new revised edition was prepared for distribution. In addition, a series of Geothermal Fact Sheets was initiated with the preparation of three, which are now under DOE review. The topics covered to date are geothermal space heating, the Raft River 5-MW power plant, and agricultural product drying. Finally, slide/cassette shows were provided the commercialization teams in ten western states along with brochures and technical reports. Each of these 12-minute shows contain information specific to geothermal activities in each state.

The volume of requests for information and technical assistance continued the dramatic growth shown in earlier reporting periods (Table 5) as more potential users learn of the
Table 5. User assistance program activity summary-January 1977 through September 1980

\begin{tabular}{ccc}
\hline Fiscal Year & $\begin{array}{c}\text { Requests for } \\
\text { Information }\end{array}$ & $\begin{array}{c}\text { Requests for } \\
\text { Technical Assistance }\end{array}$ \\
\cline { 3 - 3 } 1977 & 24 & 10 \\
1978 & 131 & 33 \\
1979 & 295 & 79 \\
1980 & 411 & 78 \\
\hline
\end{tabular}

availability of this program. A total of 575 requests for information from 411 individuals and 83 requests for technical assistance from 78 parties were received, continuing to exceed manpower availability and resulting in a carryover into FY 1981 of 30 requests. Seven subcontracts were issued to engineering firms to assist in providing assistance, as well as to build expertise in the private sector. These efforts have involved projects that would provide space heating to senior citizens facilities, offices, commercial buildings, residences, schools, and hospitals, and process heat for methane and alcohol production. Four of these efforts were completed in the last six months, and one was terminated due to the requester's death. Two of the subcontracts are to be completed in FY 1981 following resource exploration. The number of subcontracting efforts will be increased during the next reporting period.

Representative projects receiving technical assistance in this reporting period include:

1. Geothermal ethanol or methane production at Kuna and Parma, Idaho sites

2. Geothermal energy for support of mining facilities near Big Creek Hot Springs, Idaho

3. Space heating for a resort greenhouse and geothermal fluid for aquaculture at Monroe, Utah

4. Space heating for a new six-story office building in Glenwood Springs, Colorado

5. Space heating for a 10-story officeresidential building renovation in Bismarck, North Dakota. 


\title{
PON AND PRDA PROJECTS
}

\author{
(F. Childs, K. Jones, L. Nelson, and J. Strawn)
}

The EG\&G Idaho Geothermal Program Office provides technical assistance to DOE for the Program Research and Development Announcement (PRDA) Program and the Program Opportunity Notice (PON) Program. Both programs were instituted to hasten the commercialization of the direct application of geothermal energy. The PRDA Program consists of a series of studies designed to investigate the engineering and economic feasibility of geothermal direct applications. The PON Program is a demonstration project program in which project costs are shared between DOE and the private companies, municipalities, or organizations that are conducting each demonstration. During this reporting period, EG\&G Idaho provided program management and technical support for 12 demonstration projects and 10 engineering and economic studies. Each project is summarized below.

\section{PON Projects}

Ore-Ida Foods, Inc., Ontario, Oregon. Ontario, Oregon is located $92 \mathrm{~km}(57 \mathrm{mi})$ northwest of Boise, Idaho. The Ontario Ore-Ida Foods, Inc., plant currently uses natural gas and oil. This project would substitute geothermal energy for potato processing heat, space heat, and hot potable water in the amount of about $97,200 \mathrm{MWh} / \mathrm{yr}\left(33.2 \times 10^{10} \mathrm{Btu} / \mathrm{yr}\right)$. Production was predicted to be $50 \mathrm{~L} / \mathrm{s}(800 \mathrm{gal} / \mathrm{min})$ at $160^{\circ} \mathrm{C}\left(320^{\circ} \mathrm{F}\right)$ from two production wells. Two production wells and one injection well were planned.

After the $3065 \mathrm{~m}(10,054 \mathrm{ft})$ deep production well reached equilibrium, a bottom hole temperature of $182^{\circ} \mathrm{C}\left(360^{\circ} \mathrm{F}\right)$ was measured. Shut-in pressure was $827 \mathrm{kPa}$ (120 psig), but flow is currently inadequate; only about $0.82 \mathrm{~L} / \mathrm{s}(13 \mathrm{gal} / \mathrm{min})$ at a

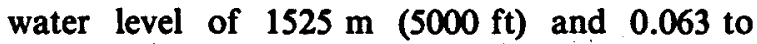
$0.126 \mathrm{~L} / \mathrm{s}$ (1 to $2 \mathrm{gal} / \mathrm{min}$ ) surface artesian flow. Also, most of DOE's funding was consumed by this one well, so no additional drilling is planned.

Pertinent electrical log data were digitized and cross plotted for additional analysis of potential fracture zones. The objective of the present analysis is to determine if the well should be considered as a candidate for use in the National Well Stimulation Program, the Hot Dry Rock Program, or other applications.

Monroe City, Utah. Monroe City is a community of 1500 people, $257 \mathrm{~km}(160 \mathrm{mi})$ south of Salt Lake City, Utah. The project planned the drilling of one production and one injection well, and installing a district heating system. The system would initially heat the South Sevier High School, two city buildings, and later expand to include the major areas of Monroe.

The proposed project expected a $120^{\circ} \mathrm{C}\left(248^{\circ} \mathrm{F}\right)$ resource with a maximum flow rate of $32 \mathrm{~L} / \mathrm{s}$ $(500 \mathrm{gal} / \mathrm{min})$, but only obtained $75^{\circ} \mathrm{C}\left(165^{\circ} \mathrm{F}\right)$ at $38 \mathrm{~L} / \mathrm{s}(600 \mathrm{gal} / \mathrm{min})$. The reduced resource dropped the peak system capacity from 6500 to $2800 \mathrm{~kW}, 43 \%$ of its expected capability.

Terra Tek, Inc., and Caldwell, Richards, and Sorensen, Inc., Monroe City's engineering consultants, completed the preliminary design. They reported that project costs would be about $\$ 921,000$ higher than budgeted, and that revenues from the smaller resource might not cover operating costs.

Since Monroe City was incapable of increasing its financial support, DOE would have to double its expenditures if the project were to proceed. accordingly, DOE-ID requested that Monroe City define an alternate use for Production Well MC.3. The alternate use should conform to the direct-use PON objectives and stay within the $\$ 500,000$ remaining in the budget.

Monroe City has not made a formal response to DOE's requests to define an alternate use for the smaller resource, so no funds were provided for the project in the FY 1981 budget. An independent review of the project cost estimate and potential alternate uses is planned to assist Monroe City in evaluating the future use of the resource.

Haakon School District, Philip, South Dakota. Haakon School is located in the town of Philip, which is approximately $129 \mathrm{~km}(80 \mathrm{mi})$ east of Rapid City, South Dakota. The project has been expanded in scope to include the space 
heating of the school complex and eight business buildings on the discharge line route. The Environmental Protection Agency required that the Ra-226 levels in the well water be reduced to $5 \mathrm{pCi} / \mathrm{L}$ prior to discharge to the Bad River. The project scope was expanded to include a water treatment facility. The water is being treated by injecting a $10 \%$ aqueous solution of barium chloride into the geothermal effluent. After a holding pond settling time of 48 hours, the water is discharged into the river. Approximately 2000 barrels of fuel oil will be replaced yearly, resulting in a payback of approximately 14 years. The pipeline installation and building retrofit have been completed and the school system is on-line for the 1980-81 heating season. A ribbon-cutting ceremony and dedication is planned for October.

St. Mary's Hospital, Pierre, South Dakota. St. Mary's Hospital, located in Pierre, South Dakota, was heated by a fossil fuel system. This project demonstrates the feasibility of utilizing low-temperature water from a 665-m (2181-ft) Madison Aquifer well for space, domestic hot water, and ventilation air heating. The well flows at a rate of $24 \mathrm{~L} / \mathrm{s}(375 \mathrm{gal} / \mathrm{min})$, at a temperature of $41^{\circ} \mathrm{C}\left(106^{\circ} \mathrm{F}\right)$, and at $186 \mathrm{kPa}(27 \mathrm{psig})$ residual pressure. The water from the well has a total dissolved solids of $2084 \mathrm{ppm}$, a hydrogen sulfide content of $0.7 \mathrm{ppm}$, and an Ra-226 level of $19 \mathrm{pCi} / \mathrm{L}$. The well water is discharged through a PVC pipe to the Missouri River. The underground piping system consists of a filament-wound fiberglass carrier pipe surrounded by polyurethane insulation jacketed with a PVC pipe.

The installation of the St. Mary's Hospital geothermal space and domestic water heating system has been completed, and is now in full operation. Ribbon-cutting ceremonies and dedication are planned for October.

The system is functioning properly and the monitoring phase of the project is in progress. In addition to providing heat to the $7432 \mathrm{~m}^{2}$ $\left(80,000 \mathrm{ft}^{2}\right)$ existing building, the geothermal system, with a heat pump, will also provide heat to the new $6503 \mathrm{~m}^{2}\left(70,000 \mathrm{ft}^{2}\right)$ hospital building which has just been completed. The geothermal system provides all space heating down to $-12.2^{\circ} \mathrm{C}$ $\left(10^{\circ} \mathrm{F}\right)$ and domestic hot water and boiler water preheat up to $37.8^{\circ} \mathrm{C}\left(100^{\circ} \mathrm{F}\right)$. Cost of the project is $\$ 718,000$.
Diamond Ring Ranch, Haakon County, South Dakota. Geothermal water from an artesian well that has flowed since 1959 is being used for grain drying and space heating on the Diamond Ring Ranch in South Dakota. The system retrofit consists of PVC pipelines connecting the wellhead to the various structures requiring heat. After flowing through the central heat exchanger, the geothermal fluid is used as stock water and then discharged into a reservoir system used for both geothermal well and runoff catchment.

The geothermal space heating and grain drying system has been completed and is now in full operation. Ribbon-cutting ceremonies and dedication are planned for October.

The system is functioning properly and the monitoring phase of the project is in progress. Problems of air pockets in the main supply line have been corrected by installing air vents in the first two high points of the supply line. In addition, the wellhead was refurbished and the wellhead leaks were stopped. Cost of the project is $\$ 403,908$.

Elko, Nevada. The Elko project involves the location and drilling of a production well to extract hydrothermal fluids for direct application. These fluids are to be used for process heat in a commercial laundry and for space heating a motor hotel and $a$ bank building.

The Resource Assessment Phase has been completed. This phase included shallow temperature probe surveys, geological reconnaissance, electrical resistivity soundings, sling ram soundings, and geochemical sampling of city wells and the Elko Hot Springs. In addition, four temperature gradient holes were drilled to further identify possible production-hole drilling sites. Test Hole

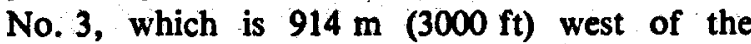
Stockmen's Motor Hotel, has been chosen as the most likely production well site. At Test Hole No. 3, temperatures in excess of $71^{\circ} \mathrm{C}\left(160^{\circ} \mathrm{F}\right.$ were encountered at a depth of $172 \mathrm{~m}(565 \mathrm{ft})$.

The Elko Heat Company has awarded a contract to Hockworth Drilling of Elko, Nevada for the production well drilling. As soon as contractual differences with the City of Elko are resolved and a state water appropriation permit is obtained, production well drilling will begin. 
Warm Springs State Mental Hospital, Montana. The objective of the project is to develop the geothermal resource at Warm Springs (near Butte, Montana) to provide domestic water and space heating at the Warm Springs State Mental Hospital. Water from the production well will be pumped through two plate-type heat exchangers and discharged into a wetlands disposal area.

The production well has been completed to a total depth of $456 \mathrm{~m}$ (1498 ft).

The well cleanout and testing phase is in progress. The well is now artesian flowing $4.42 \mathrm{~L} / \mathrm{s}$ $(70 \mathrm{gal} / \mathrm{min})$ at $73.3^{\circ} \mathrm{C}\left(164^{\circ} \mathrm{F}\right)$. Initial tests indicate considerable wellbore damage. However, due to test pump malfunctions, long term drawdown tests could not be conducted. The failed shaft-type test pump was removed and preparations are being made to test the well using a submersible pump. Several pump companies have submitted bids to test the well and the contractor is presently installing the necessary higher-voltage electrical power at the well site.

Pagosa Springs, Colorado. The geothermal resource in Pagosa Springs has been used on a limited basis since the early 1900 s. Nearly 30 wells have been drilled for heating and recreational purposes. Flow and disposal rights from some of these wells will be transferred to the demonstration project's district heating system. Most of the town's public buildings will be heated by the geothermal energy with provision for connecting commercial and residential buildings to the system.

Based on the Resource Report and the questionable structural integrity of existing wells, it was decided to drill two $90 \mathrm{~m} \mathrm{(300} \mathrm{ft)} \mathrm{production}$ wells. Drilling relied heavily on the data from nearby Wells P-1 and 0-2, which were managed by the Colorado Geological Survey under DOE sponsorship. The $60^{\circ} \mathrm{C}\left(140^{\circ} \mathrm{F}\right)$ target aquifer proved very site-dependent, even with site moves as little as $9 \mathrm{~m} \mathrm{(30} \mathrm{ft).} \mathrm{It} \mathrm{was} \mathrm{necessary} \mathrm{to} \mathrm{drill} \mathrm{three} \mathrm{wells}$ to get two good producers.

Well PS-3 was artesian flow tested at $37.9 \mathrm{~L} / \mathrm{s}$ $(600 \mathrm{gal} / \mathrm{min})$ and $55^{\circ} \mathrm{C}\left(131^{\circ} \mathrm{F}\right)$ for 12 hours from the $76 \mathrm{~m}(250 \mathrm{ft})$ deep aquifer. An aquifer at $34 \mathrm{~m}(110 \mathrm{ft})$ with $59^{\circ} \mathrm{C}\left(138^{\circ} \mathrm{F}\right)$ temperature had inadequate flow and was sealed off by casing.
Well PS-4, near the western edge of the resource

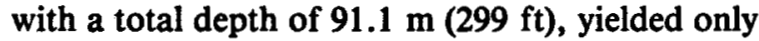
a total artesian flow of $14.4 \mathrm{~L} / \mathrm{s}(228 \mathrm{gal} / \mathrm{min})$ at $48^{\circ} \mathrm{C}\left(118^{\circ} \mathrm{F}\right)$. Both flow and temperature were inadequate so the well was plugged to avoid aquifer crossflow and to minimize completion costs.

Well PS-5, one of the hottest and most productive in the area, artesian flows at $65^{\circ} \mathrm{C}\left(149^{\circ} \mathrm{F}\right)$. It was flow tested at $72.6 \mathrm{~L} / \mathrm{s}(1150 \mathrm{gal} / \mathrm{min})$ for 12 hours at $50.5 \mathrm{~L} / \mathrm{s}(800 \mathrm{gal} / \mathrm{min})$ for 72 hours. Then, simultaneously, Well PS-3 was flowed at $12.6 \mathrm{~L} / \mathrm{s}(200 \mathrm{gal} / \mathrm{min})$ and Well PS-5 at $44.2 \mathrm{~L} / \mathrm{s}$ (700 gal $/ \mathrm{min})$ for about seven days. The reservoir capacity appears adequate for the peak $63.09 \mathrm{~L} / \mathrm{s}$ (1000 gal/min) district heating system.

The final system design continued, and identified an estimated cost increase of $\$ 361,000$ (36\%) due to additional drilling, drilling problems, and inflation of construction costs. A draft design was received for DOE review on September 24.

A drive-in restaurant plans to use the $65^{\circ} \mathrm{C}$ $\left(149^{\circ} \mathrm{F}\right)$ water, from Well PS-5 directly in their heating system this winter. Some components will be added to their system for testing.

Utah Roses, Sandy, Utah. The Utah Roses greenhouse complex is located in the town of Sandy, which is approximately $17 \mathrm{~km}(11 \mathrm{mi})$ south of Salt Lake City, Utah. The complex consists of $23,500 \mathrm{~m}^{2}(6 \mathrm{~A})$ of greenhouses that produce cut roses for the national floral market. A production well, drilled to a depth of $1525 \mathrm{~m}$ $(5009 \mathrm{ft})$ produces water at a pumped flow rate of $12.6 \mathrm{~L} / \mathrm{s}(200 \mathrm{gal} / \mathrm{min})$ at a temperature of $50^{\circ} \mathrm{C}$ $\left(122^{\circ} \mathrm{F}\right)$ with a drawdown of about $366 \mathrm{~m}$ (1200 ft).

The geothermal water will be piped through water-to-air heat exchangers and the heated air distributed in large, thin-film polyethylene tubes throughout the greenhouse. The water will then be piped in the ground alongside the plants to use the maximum amount of available heat. The present plan, which needs permitting approval, is to discharge the geothermal fluid into a nearby waste canal, which flows directly into the Jordan River.

The system will have a simple payback of approximately 9 years. It will be installed during the summer of 1981 and on-line for the 1981-82 heating system. 
Utah State Prison, Draper, Utah. The Utah State Prison is located in Salt Lake County approximately $27 \mathrm{~km}(17 \mathrm{mi})$ south of Salt Lake City. The resource surface expression, known as Crystal Hot Springs, is adjacent to the prison. A geothermal well has recently been drilled at the springs for a commercial greenhouse project and produces water at $88^{\circ} \mathrm{C}\left(190^{\circ} \mathrm{F}\right)$ and an artesian flow rate of $12.6 \mathrm{~L} / \mathrm{s}(200 \mathrm{gal} / \mathrm{min})$. The minimum security section of the prison will be retrofitted to utilize the heat from a well to be funded by DOE. Gravity and magnetic surveys have been completed for the area and test holes are planned for the fall of 1980 .

Madison County, Idaho. Madison County and the city of Rexburg are at the eastern edge of the Snake River Plain, where northeast trending faults, concentrated along the plain boundaries, are the source of many hot springs.

The Madison County geothermal project plans to demonstrate a low-temperature geothermal resource for food processing and district space heating.

Two production wells at 914 and $830 \mathrm{~m}$ (3000 and $6000 \mathrm{ft}$ ) were proposed. The deep well was expected to supply $121^{\circ} \mathrm{C}\left(250^{\circ} \mathrm{F}\right)$ water to a potato processing company for use in food processing followed by cascading usage for space heating with an $88^{\circ} \mathrm{C}\left(190^{\circ} \mathrm{F}\right)$ supply temperature.

It was decided to drill a 914- to 1524-m (3000- to 5000-ft) production well (MCG-1) near HTW-1 at the junction of major faults near Rexburg, Idaho. Intersection of the fault was predicted to be between 762 and $1524 \mathrm{~m}$ (2500 and $3000 \mathrm{ft}$ ).

Well MCG-1 was spudded on June 30. It was drilled at a TD of $3933 \mathrm{ft}$, airlift flowed at about $44.2 \mathrm{~L} / \mathrm{s}$ ( $700 \mathrm{gal} / \mathrm{min})$, temperature logged, and cleaned until July 4 when the rig was released. The fault was intersected at $1524 \mathrm{~m}(3000 \mathrm{ft})$, but found cold water ascending rather than hot water descending. Water temperature never climbed above $21.7^{\circ} \mathrm{C}\left(71^{\circ} \mathrm{F}\right)$.

About the middle of July, the USGS logged the well, but it was bridged at $853 \mathrm{~m}(2800 \mathrm{ft})$. They found a downward flow of $3.8 \mathrm{~L} / \mathrm{s}(60 \mathrm{gal} / \mathrm{min})$ from 731 to $853 \mathrm{~m}$ (2400 to $2800 \mathrm{ft}$ ). Project management requested permission to reopen the hole to total depth and install a liner to determine if some warm zones exist near the bottom. It was postulated that these warm lower zones cannot produce against the borehole pressure, and have not been seen because the lower $143 \mathrm{~m}$ (470 ft) have never been logged. DOE-ID is considering the request.

Boise, Idaho. The objective of the Boise City/Boise Warm Springs Water District Geothermal Project is to develop a geothermal space heating system to serve the largest possible commercial and residential market in the Boise central business district and neighboring residential areas.

During this reporting period, DOE approved the environmental and geological assessments submitted in the last reporting period. Bid specifications for three wells: Boise City Nos. 1 and 2 and Boise Warm Springs Water District (BWSWD) No. 3 were submitted, reviewed, and approved. The preliminary engineering design report was also submitted, reviewed, and approved; the financial and institutional plan is still due.

Bid requests for the BWSWD No. 3 well were advertised in September and a contract to begin well drilling will probably be awarded in December.

The Idaho Department of Health and Welfare granted Boise City a permit to dispose of up to $170 \mathrm{~L} / \mathrm{s}(2700 \mathrm{gal} / \mathrm{min})$ into the Boise River. The state, however, reserves the right to revoke up to $2 / 3$ of the allowed discharge if the city develops its own geothermal heating system, for state-owned buildings, that requires effluent disposal. The state has completed an exploration well to $664 \mathrm{~m}$ $(2180 \mathrm{ft})$ with a reported bottom hole temperature of $64^{\circ} \mathrm{C}\left(147^{\circ} \mathrm{F}\right)$.

Funding sources and cost shares for the $\$ 8.3$ million contract have been identified, and the current DOE contract with Boise City was extended through September 30, 1981.

\section{PRDA Projects Completed or in Progress}

The following study projects were completed or in progress at the end of the reporting period. 
Residential and Commercial Space Heating and Cooling with Possible Greenhouse Operation: Baca Grande Development, San Luis Valley, Colorado. This study is being conducted by Coury and Associates, Inc., of Lakewood, Colorado. The objective is to investigate the multipurpose commercial application of moderate-temperature geothermal waters at the Baca Grande Community Development in the San Luis Valley. The final report was submitted in June, approved in July, and published to complete the project.

Direct Application of Goethermal Energy at the L'eggs Products Plant, Las Cruces, New Mexico. The Energetics Corporation of Dallas, Texas, is conducting a study to evaluate five potential geothermal resource areas for use in the L'eggs Plant processes. A preliminary system design was developed and the study was completed in September.

Direct Application of Geothermal Energy for Ethanol Production for Automotive Fuel Usage. Bechtel National, Inc., completed the study to evaluate the Raft River, Idaho, geothermal resource for use in producing ethanol. A $76 \times 10^{6}$-L $\left(20 \times 10^{6}\right.$-gal) per year facility utilizing potatoes, wheat, and sugar beets as feedstocks has been designed. The study was completed in August.

Evaluation of Direct Hot Water Geothermal Applications on the University of New Mexico Campus. The objective of this project was to determine the economic and engineering feasibility of heating and cooling approximately $25 \%$ of the university campus with low-temperature geothermal energy. The draft final report was submitted in September and is undergoing review.

Municipal Geothermal Heat Utilization Plan for Glenwood Springs, Colorado. The objective of this study was to assess the economic and engineering feasibility of supplying geothermal heat to several city buildings and a municipal wastewater-treatment facility. The draft final report was submitted in September and is undergoing review.

Geothermal Space Heating in Poplar, Montana. This study is being conducted by PRC Toups, Inc., and the Council of Energy Resource
Tribes. The primary objective of the project was to define the feasibility of using the Madison Aquifer resource for district heating in the Poplar Dome area. The draft final report was reviewed in August and the revised final report is expected in October.

\section{New PRDA Projects}

Technical and cost evaluation for the following four new PRDA projects were completed in September. The evaluations will assist DOE in upcoming contract negotiations for each project. The projects are:

Great Western Malting. The full PRDA title is "Resource, Engineering and Economic Study for the Great Western Malting Co., Geothermal Project," submitted by Trans Energy Systems, Inc. The objective of this study is to determine if well drilling and heat recovery system construction is justified:

Salida Geothermal. The full PRDA title is "Resource, Engineering and Economic Study for Direct Heat Applications of Geothermal Energy at the Salida (Colorado) Geothermal Project,"' submitted by Chaffee Geothermal, Ltd. The objective of this study is to study the direct heat applications of the Poncha Springs-Salida Geothermal Prospect to the industrial process heat requirements of CoZinCo, Inc., and to other prospective energy users in Salida.

Vale Alcohol. The full PRDA title is "Engineering, Marketing and Economic Study of a 4.5 million-gallon Geothermal Fuel Alcohol Plant for the Vale Geopark Site," submitted by Technology International, Inc. The objectives of this project are to drill a $1500 \mathrm{ft}$ well for resource assessment, determine economic and institutional factors, and generate a preliminary design for-a fuel alcohol plant.

San Luis Valley Ethanol. The full PRDA title is "Commercial Production of Ethanol in the San Luis Valley, Colorado," submitted by Westec services/McCulloch Geothermal Corp. The objective of this study is to investigate the feasibility of using geothermal energy in the San Luis Valley, Colorado, to provide all or part of the total energy requirements of a 20- to 50-million-gallon-peryear ethanol production plant. 


\section{REFERENCE}

1. S. L. Milora and J. W. Tester, Geothermal Energy as a Source of Electric Power; Thermodynamic and Economic Design Criteria, Cambridge: The MIT Press, 1976. 


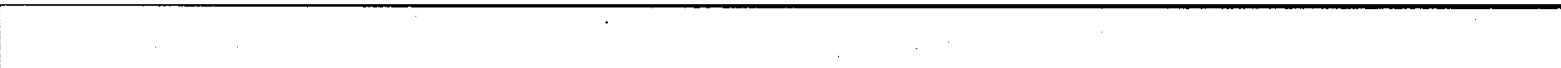




\section{APPENDIX A}

PUBLICATIONS OF THE IDAHO GEOTHERMAL PROGRAM 



\section{APPENDIX A}

\section{PUBLICATIONS OF THE IDAHO GEOTHERMAL PROGRAM}

Table A-1 lists the formal reports published by EG\&G Idaho, Inc., for the : Idaho Geothermal Program. Printed or microfiche copies of these reports may be ordered from the National
Technical Information service, U.S. Department of Commerce, 5285 Port Royal Road, Springfield, Virginia 22161.

Table A-1. EG\&G Idaho, Inc., formal reports of the Idaho Geothermal Program

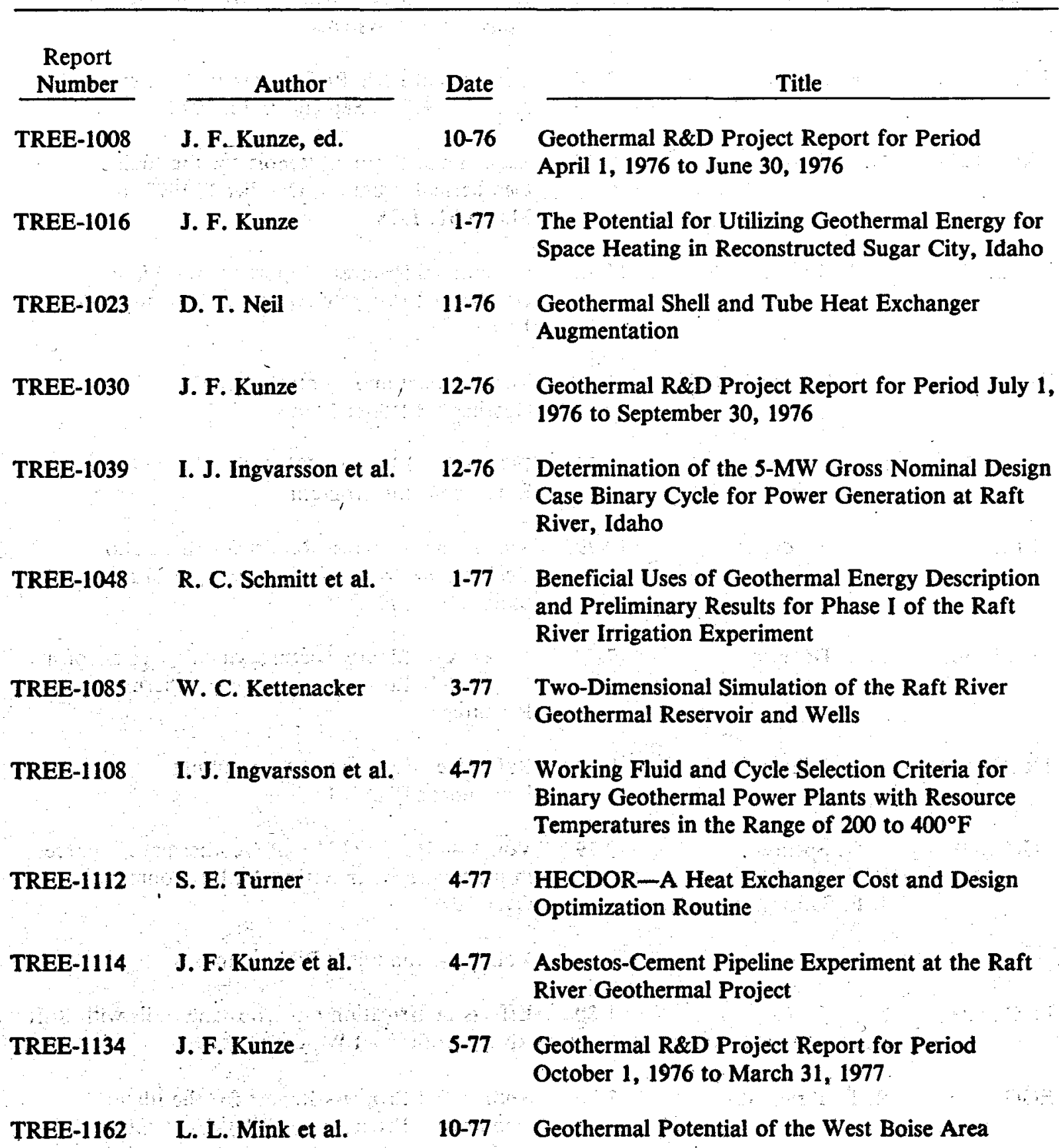




\begin{tabular}{|c|c|c|c|}
\hline Number & Author & Date & Title \\
\hline TREE-1164 & C. J. Shaffer & 8-77 & $\begin{array}{l}\text { Floating Power Optimization Studies for the Cool- } \\
\text { ing System of a Geothermal Power Plant }\end{array}$ \\
\hline TREE-1176 & R. L. Miller & $10-77$ & $\begin{array}{l}\text { Results of Short-Term Corrosion Evaluation Test } \\
\text { at Raft River }\end{array}$ \\
\hline TREE-1182 & I. A. Engen & $2-78$ & $\begin{array}{l}\text { Residential Space Heating Cost: Geothermal vs } \\
\text { Conventional Systems }\end{array}$ \\
\hline TREE-1256 & J. F. Kunze & 3-78 & $\begin{array}{l}\text { Geothermal R\&D Project Report for Period } \\
\text { April 1, } 1977 \text { to September } 30,1978\end{array}$ \\
\hline TREE-1278 & G. L. Blake, ed. & 7-78 & $\begin{array}{l}\text { Semiannual Progress Report for the Idaho } \\
\text { Geothermal Program, October 1, } 1977 \text { to } \\
\text { March 31, } 1978\end{array}$ \\
\hline TREE-1295 & G. L. Blake, ed. & $11-78$ & $\begin{array}{l}\text { Semiannual Progress Report for the Idaho } \\
\text { Geothermal Program April } 1 \text { to September 30, } \\
1978\end{array}$ \\
\hline TREE-1312 & J. F. Whitbeck et al. & $1-79$ & $\begin{array}{l}\text { Measurement and Control Techniques in } \\
\text { Geothermal Power Plants }\end{array}$ \\
\hline TREE-1340 & S. G. Spencer et al. & 4-79 & $\begin{array}{l}1978 \text { Annual Report, INEL Geothermal } \\
\text { Environmental Program }\end{array}$ \\
\hline TREE-1359 & L. F. Burdge et al. & $10-79$ & $\begin{array}{l}\text { Semiannual Progress Report for the Idaho } \\
\text { Geothermal Program, October 1, } 1978 \text { to } \\
\text { March 31, } 1979\end{array}$ \\
\hline TREE-1365 & O. J. Demuth & 7-79 & $\begin{array}{l}\text { Analysis of Binary Thermodynamic Cycles for a } \\
\text { Moderately Low-Temperature Geothermal } \\
\text { Resource }\end{array}$ \\
\hline TREE-1370 & J. F. Sullivan et al. & $9-79$ & $\begin{array}{l}\text { Raft River Geothermal Aquaculture } \\
\text { Experiment-Phase II }\end{array}$ \\
\hline \multirow[t]{2}{*}{ EGG-2001 } & $\begin{array}{l}\text { S. G. Spencer } \\
\text { B. F. Russell } \\
\text { J. F. Sullivan }\end{array}$ & 9-79 & $\begin{array}{l}\text { Vol. } 1 \text { - Potential Use of Geothermal Resources } \\
\text { in the Snake River Basin: An Environmental } \\
\text { Overview }\end{array}$ \\
\hline & & & Vol. 2 - Annotated Bibliography \\
\hline EGG-2005 & $\begin{array}{l}\text { N. E. Stanley } \\
\text { R. C. Schmitt }\end{array}$ & $1-80$ & $\begin{array}{l}\text { Effects of Irrigation on Crops and Soils with Raft } \\
\text { River Geothermal Water }\end{array}$ \\
\hline EGG-2010 & R. R. Ihrig, ed. & $3-80$ & $\begin{array}{l}\text { Semiannual Progress Report for the Idaho } \\
\text { Geothermal Program April } 1 \text { to September } 30 \text {, } \\
1979\end{array}$ \\
\hline
\end{tabular}


Table A-1. (continued)

\begin{tabular}{|c|c|c|c|}
\hline $\begin{array}{l}\text { Report } \\
\text { Number }\end{array}$ & Author & Date & Title \\
\hline EGG-2013 & J. G. Keller & $3-80$ & $\begin{array}{l}\text { Geothermal Direct Applications Hardware Systems } \\
\text { Development and Testing-1979 Summary Report }\end{array}$ \\
\hline EGG-2028 & T. L. Thurow & 4-80 & $\begin{array}{l}1979 \text { Annual Report INEL Geothermal } \\
\text { Environmental Program }\end{array}$ \\
\hline EGG-2029 & $\begin{array}{l}\text { N. E. Stanley } \\
\text { T. L. Thurow } \\
\text { B. F. Russell } \\
\text { J. F. Sullivan }\end{array}$ & $5-80$ & $\begin{array}{l}\text { Geothermal Wetlands: An Annotated Bibliography } \\
\text { of Pertinent Literature }\end{array}$ \\
\hline EGG-2034 & R. R. Ihrig & $7-80$ & $\begin{array}{l}\text { Semiannual Progress Report for the Idaho } \\
\text { Geothermal Program October 1, } 1979 \text { to March 31, } \\
1980\end{array}$ \\
\hline EGG-2036 & $\begin{array}{l}\text { L. T. Cole } \\
\text { R. C. Schmitt }\end{array}$ & $6-80$ & $\begin{array}{l}\text { Fluidized-Bed Potato Waste Drying Experiments at } \\
\text { the Raft River Geothermal Test Site }\end{array}$ \\
\hline EGG-2054 & $\begin{array}{l}\text { T. L. Thurow } \\
\text { C. M. White } \\
\text { R. P. Howard } \\
\text { J. F. Sullivan }\end{array}$ & $9-80$ & Raptor Ecology of Raft River Valley, Idaho \\
\hline EGG-2057 & $\begin{array}{l}\text { S. G. Spencer } \\
\text { D. M. Callan }\end{array}$ & $9-80$ & $\begin{array}{l}\text { An Analysis of the Response of the Raft River } \\
\text { Monitor Wells to the } 1979 \text { Injection Tests }\end{array}$ \\
\hline
\end{tabular}

